\title{
骨盤骨折の骨折型と死亡例の関係
}

国立長崎中央病院整形外科

$\begin{array}{rllllll}\text { 中 } & \text { 村 } & & \text { 智・藤 } & \text { 田 } & \text { 雅 } & \text { 章 } \\ \text { 大 } & \text { 坪 } & \text { 義 } & \text { 昌・本 } & \text { 川 } & \text { 哲 } \\ \text { 楢 } & \text { 林 } & \text { 葉 } & \text { 子 } & & & \\ \text { 長崎大学整形外科 } & & & & \\ \text { 岩 崎 } & \text { 勝 } & \text { 郎・伊 } & \text { 藤 } & & \text { 茂 }\end{array}$

\section{Relationship between the Type of Pelvic Fracture and Mortality}

by

\author{
Satoshi Nakamura, Masaaki Fujita, Yosimasa Ohtubo, \\ Satoru Motokawa and Yoko Narabayasi \\ Department of Orthopaedic Surgery, \\ Nagasaki Chuo National Hospital \\ Katsuro Iwasaki and Shigeru Itoh \\ Department of Orthopaedic Surtery, Nagasaki Unibersity School of \\ Medicine, Nagasaki Japan
}

Pelvic fracture, especially the type in which the pelvic ring is destroyed, influences mortality, so careful clinical treatment is required. We treated 60 cases of pelvic fractures from 1987 to 1993.

The pelvic fracture was classified according to the method of Key and Conwell. Eight cases had died and all of these deaths had been caused by severe compications especially associated with type 3 frachires (by Key and Conwell) which had a high mortality rate caused by fatal compications.

Trans Arterial Embolization (TAE) was effective in a patient with hypovolemic chock caused by bleeding following a type 3 pelvic fracture with no other complications.

Key words : pelvic fracture (骨盤骨折), mortality rate (死亡率), Key and Conwell Classification (キイ・コンウェル分類)

はじめに

近年, high energy trauma の増加に伴って骨盤骨 折の症例が増加してきている。.さまざまな外傷の中で も骨盤骨折，特に骨盤輪が破壊されるタイプは生命的 予後に与える影響が大きいと言われており ${ }^{11}$ ，初期治 療には注意を要する。本研究は, 骨盤骨折の骨折型と 生命的予後の関係を明らかにする目的で行った。

\section{対象および方法}

当院では 1987 年から 1993 年までの間に 60 例の骨 盤骨折があった。年齢は 8 才から 84 才，平均 47.9 才， 男性 42 例，女性 18 例であった。

受傷原因は交通事故が 60 例中 46 例と圧倒的に多く, その中で自動車, バイク乗車中の事故が 20 例あった. その他労災事故などのほとんどが high energy traumaであった。 
表 1 Key and Conwell の分類 ${ }^{3)}$ 4)

I. Fractures of individual bones without a break in the continuity of the pelvic ring

A. Avulsion fractures

1. Anterior superior ilic spine

2. anterior inferior iliac spine

B. Fracture of pubis or ischium

C. Fracture o the wing of the ilium (Duverney)

D. Fracture of the sacrum

E. Fracture of dislocation of the coccyx

II. Single break in the pelvic ring

A. Fracture of two ipsilateral rami

B. Fracture near, or subluxation of, the symphy. sis pubis

C. Fracture near, or sublunxation of, the sacro iliac joint

III. Double breaks in the pelvic ring

A. Double vertical fractures or dislocation of the pubis (straddle fractures)

B. double vertical fractures or dislocations of the pelvis (Malgaigne)

C. Severe multipe fractures

IV. Fractures of the acetabulum
A. Undisplaced
B. Displaced

骨折型は，我々は骨盤輪に関与するか否かを中心に 解剖学的部位によって分類した Key and Conwell の 方法を使用した (表 1$)^{4)}$. 全症例をこの Key and Conwell の方法に準じて分類し，それぞれのタイプ と合併症, 死亡率の関連などについて検討した。

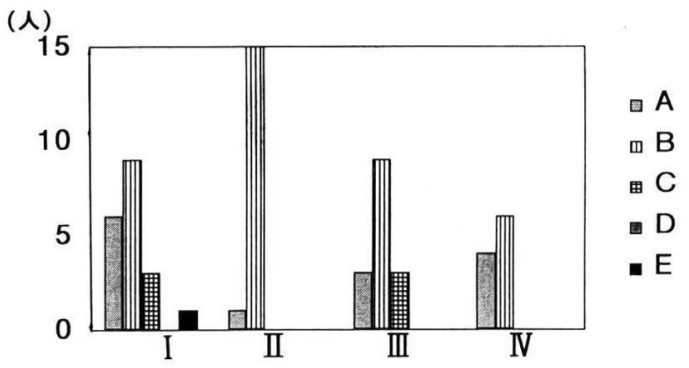

図 1 Key and Conwell 分類による骨折型別の症 例 数を示す (Type I - A E, Type II - A $\sim \mathrm{C}$, Type III-A C, Type IV $-\mathrm{A}, \mathrm{B})$. Type I, II, IIIおよびIVの総数はそれぞれ 19， $16 ， 15$ および 10 であった。
表 2 骨折型別の合併症

\begin{tabular}{lccccr}
\hline \hline & I & II & III & IV & V \\
\hline 血管 損 傷 & 0 & 0 & 9 & 0 & 9 \\
尿 路 損 傷 & 2 & 1 & 4 & 1 & 8 \\
頭 部 外 傷 & 4 & 5 & 8 & 2 & 19 \\
腹腔内損傷 & 1 & 2 & 2 & 1 & 6 \\
胸腔内損傷 & 1 & 1 & 2 & 0 & 4 \\
他骨 折 & 4 & 2 & 6 & 3 & 15 \\
\hline
\end{tabular}

表 3 骨折型別の直接の死亡原因

\begin{tabular}{|c|c|c|c|c|}
\hline & I & II & III & IV \\
\hline 血 管 損 傷 & & & & \\
\hline 尿 路 損 傷 & & & & \\
\hline 頭 部 外 傷 & 1 & 1 & 2 & \\
\hline $\begin{array}{l}\text { 腹腔内損傷 } \\
\text { (含む } \mathrm{MOF} \text { ) }\end{array}$ & & & 2 & \\
\hline 胸腔内損傷 & & & 1 & \\
\hline 他骨折 & & & & \\
\hline 不 & & & 1 & \\
\hline 計 & 1 & 1 & 6 & 0 \\
\hline
\end{tabular}

結 果

II - Bが 15 例と最も多く， I - B , III - Bがそれ ぞれ 9 例であった（図 1 ).

それぞれの症例の合併症をこの骨折型の分類別を示 す (表 2 )。この結果から骨盤輪に破綻を来す type III に最も多くの合併症が存在し, しかもその内容は頭部 外傷や血管損傷などの生命的予後に大きな影響をあた える重篤なものが多い傾向を示した.

骨盤骨折 60 例中 8 例の死亡例があった。 その直接 の死亡原因と骨折型の関係を示す (表 3 ). 死亡例が 最も多かったのは type III骨折で, 合併症としての腹 腔内損傷や頭部外傷が死因の大きな要因となっていた. 合併症のない骨盤骨折単独で死亡した症例はなかった。

死亡率は全体の平均で $13.3 \%$, 骨折型別では type I，II，IIIおよびIVはそれぞれ 5.2\%，6.3\%，40.0\% および $0 \%$ あっった。合併症を有する症例の死亡率は 全体で $29.6 \%$ ，骨折型別ではそれぞれ $20.0 \% ， 12.5 \%$ ， 54.5\%および0\%であった。 


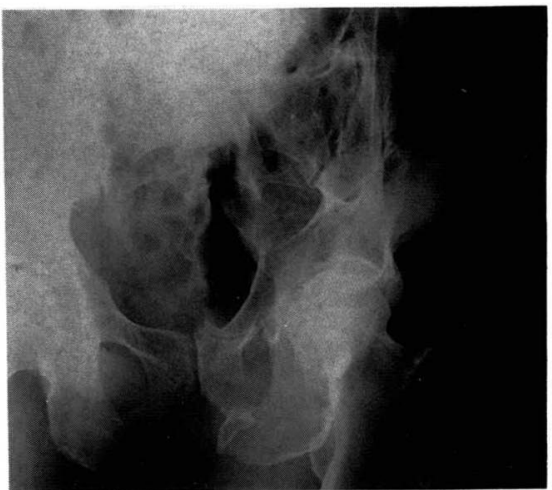

A

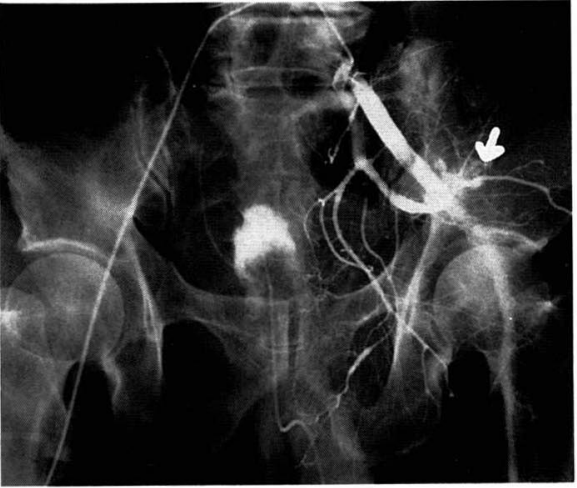

B

図262 歳男性

A : 交通事故により受傷.

Key and Conwell type III-Bであった.

B : Angiogram.

上殿動脈の損傷部を矢印で示す.

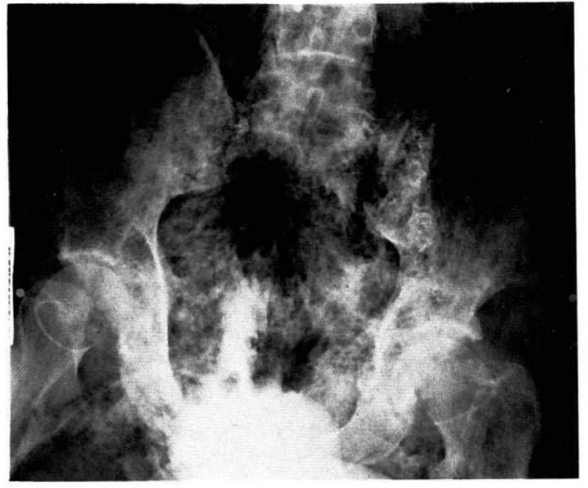

A

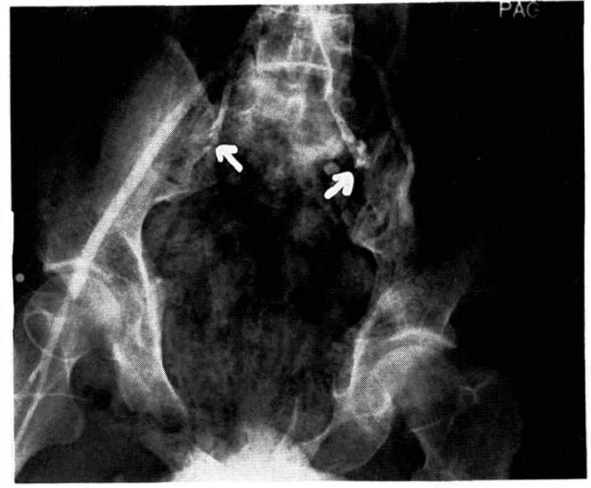

B

図351 才男性

A：交通事故により受傷.

Key and Conwell type III-Cであった.

B : Angiogram.

両側内腸骨動脈の損傷部を矢印で示す.

症

例

症例 1 (図 2)：骨折型は type III-B, 肝蔵, 脾 臓の挫傷および血管造影にて上殿動脈の損傷を認めた. 内腸骨動脈塞栓術（TAE）を施行, 出血性ショック を離脱し, 3 力月後に退院した.

症例 2（図 3)：骨折型は type III - C, 腹腔内臓 器損傷および両側内腸骨動脈損傷を認めた. 両側内腸 骨動脈塞栓術を施行，骨盤骨折による出血性ショック
を離脱したものの, 多臓器不全を引き起こし, 1 週後 に死亡した。

症例 3（図 4)：骨折型は type IV, 寛骨臼から坐 骨に至る開放骨折，坐骨の一部および，会陰部から S 状結腸にかけて久損を認めた. 受傷同日外科にてデブ リードマン, 人工肛門造設を行ったが, 術後創部より 感染をおこした。腹膜炎を併発し, 細菌性ショックの 状態となったが抗生剤投与にて軽快した. 


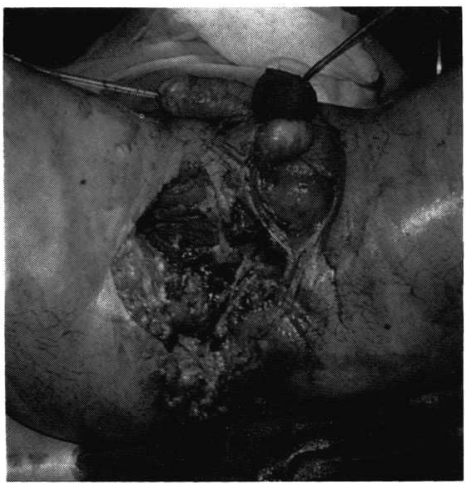

A

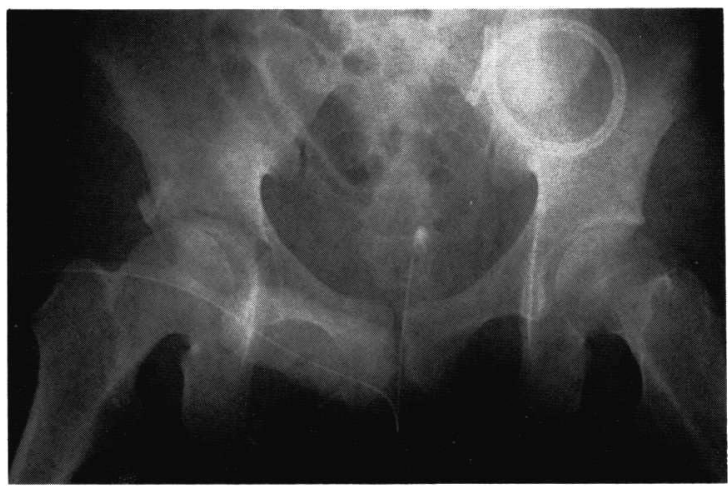

B

図 421 才男性

A：交通事故により受傷. 会陰部の開放創を示す.

B：X線写真を示す. Key and Conwell type IIIーCであった。

考

察

重症骨盤骨折は致命率が高いことで知られている。 岩田等の報告によると type I からIVの順に,それぞれ $2.1 \% ， 0.0 \% ， 11.8 \% ， 4.1 \%$ とっており ${ }^{2)}$ ，我々の 症例でもほほ同様の傾向であった。骨盤骨折単独では ただ出血量だけが死亡率を左右する唯一の因子である といわれているが5), type IIIの骨折には腹腔内損傷, 頭部外傷が合併することが多く，死亡率を上昇させる 大きな原因になっていると考えられた。

骨盤輪の大きな破綻をきたす外傷では当然他の重篤 な損傷を合併している確立が高いと考えられ，したがっ て骨折型そのものとの関連よりも合併した他の外傷が 生命的予後に大きな影響を与えていると思われる。そ れら合併症のうち骨盤骨折に伴う動脈損傷については 当院では transarterial embolization（tae）を積極 的に施行している.9 例の TAE 施行例は, 全例 type III骨折であったが，すべて一応は骨盤骨折による出血 はコントロールできていた，症例は少ないものの，こ のことが type IIIの骨盤骨折単独による致命率低下に 大きく貢献していると考えられた。

また骨盤の開放骨折は特に致命率が高いといわれて (るが ${ }^{3)}$ 症例 3 では腹腔内のデブリードマン, 人工肛 門造設, 集中的な抗生剂投与などの処置で救命できた。

以上のことは，骨盤骨折の合併症に対して，適切な 初期治療を行うことによって生命的予後が改善できる ことを示していた。
結

語

（1） 1987 年から 1993 年までの間，当院で 60 例の 骨盤骨折を経験した。

(2) Key and Conwell 分類では type Iが最も多かっ たが，合併症を有する率，死亡率ともに type IIIが最 も高かった。

（3）当院においては骨盤骨折患者における直接の死 亡原因は，ほとんどが合併損傷によるものであった。

（4）骨盤骨折そのものによる出血性ショックには TAE（transarterial embolization） が有効な救命 手段であった。

\section{参 考 文 献}

1) Baker SP et al : The injury severity score. A method for discribing patients with multiple injuries and evaluating emergency care. J. Trauma, $14: 187$ 196, 1974.

2）岩田清二：他藏器損傷を合併した骨盤骨折一死亡例を 中心绝一詛折, $11: 261-264,1989$.

3）岩田清二：骨盤骨折の病態と治療について日整会誌, $67: 102-117,1993$.

4) Rockwood, C. A. : Fracture in adults, 2. p. 1112, J. B. Lippincott Co., Philadelphia, 1984.

5）渡辺仁：骨盤環骨折。整災外，28：737-741，1985。 